\title{
Social Protection for the Elderly During the Covid-19 Pandemic
}

\author{
Nurasih Shamadiyah ${ }^{1, *}$ Achmadi Jayaputra ${ }^{2}$ \\ ${ }^{1}$ Institute for Sustainable Development and Learning, Leuphana University of Lüneburg, Germany \\ ${ }^{2}$ Pusat Pengembangan Ketahanan Sosial Masyarakat Kementerian Sosial RI, Indonesia \\ ${ }^{*}$ Corresponding author. Email: Nurasih.Shamadiyah@stud.leuphana.de
}

\begin{abstract}
Exposure cases to Covid-19 in Indonesia continue to increase, and from time to time there is a substantial increase, and it is not yet known when it will stop, and it is feared that it will continue to rise. One of the most at risk / vulnerable to Covid-19 exposure is the elderly population. Because of their physical state, elderly people, whoever they live with are in fact extremely vulnerable to being exposed to Covid-19. Elderly citizens who live in institutions of social care, for example, the Centre for Elderly Social Rehabilitation (BRSLU), which is operated by the central government (Ministry of Social RI), the Social Rehabilitation Institution for Elderly Protection (PSRPLU), which is managed by the local government, and the Social Welfare Institution for Elderly Age (LKSLU), which is organized by the community, have an important role to play in the protection of the elderly throughout their lifetime. The focus of this study is to identify the social security of the elderly in social services institutions coordinated by the government, the local government and the community during the Covid-19 pandemic, and to identify the priority needs of these elderly social services institutions to provide social protection during the Covid-19 pandemic. On the basis of the implementation of social protection during the Covid-19 pandemic, senior social protection agencies coordinated by the government, local governments, and the community. It is concluded that the social security of the elderly during the Covid-19 pandemic by these organizations is carried out by improvements in activities and refocusing the budget.
\end{abstract}

Keywords: Social protection, Elderly, Covid-19, Social institution

\section{INTRODUCTION}

Indonesia is prediction entering an aging population, which is marked by an increasing percentage of the elderly population reaching 10.6 in 2020 [1]. Currently, number of elderly people is 25.66 million (9.6 percent) [2]. Projection of BPS 2015-2045, life expectancy of the Indonesian population, from 69.8 years (2010) to 73.4 years $(2020)$, and will increase again to 75.5 years in 2045 [1].

This data illustrates the success of development, particularly in the health sector, due to the availability of health infrastructure, which continues to increase in number, and the quality is getting better, starting from the village/ sub-district to the central level. In addition, there is also a need for the elderly population through various programs, such as: family support, emergency social services for the elderly, day care services, tough elderly services, integrated service post for elderly, and development of elderly friendly areas, including the availability of nursing-based elderly services. However, the bad news, regarding the current Coronavirus Disease-19 (Covid-19) pandemic is that the elderly generally face the risk of being exposed to Covid-19. WHO data shows that more than 95 percent of deaths occur at the age of more than 60 years or older [3].

Cases of exposure to Covid-19 in Indonesia continue to increase and experience a significant increase from time to time, and it is not yet known when it will end, and it is feared that it will continue to grow. The elderly population is one of the most at risk / vulnerable to being exposed to Covid-19. Because with increasing age, there will be an increasing tendency to get sick and have physical limitations (disabled) as a result of a fairly drastic decrease in physical abilities [4, 5 , 6]. In line with this, the Covid-19 pandemic 
increases the risk of vulnerability of the elderly, because limited mobility due to the stay at home policy makes it difficult for the elderly to access basic services such as health services [7]. In addition to the limited access for elderly people to other social protection, such as earning income, the elderly are more vulnerable to economic shocks. The position of the very vulnerable elderly certainly needs protection.

There are several patterns of residence for Indonesian elderly people, the majority are with three generations (40.64 percent), with their family (27.30 percent) and only live with their partner, amounting to 20.03 percent. Meanwhile, 9.38 percent live alone [6]. Elderly, whoever they live with, actually have a high enough vulnerability to being exposed to Covid-19, because of their physical condition. Elderly who live in social service institutions / institutions, such as: the Center for Elderly Social Rehabilitation (BRSLU) which is managed by the central government (Ministry of Social RI), the Social Institution for Rehabilitation of Elderly Protection (PSRPLU) which is managed by the local government, and the Social Welfare Institution for the elderly Age (LKSLU), which is organized by the community, has an important role in protecting the elderly during the Covid-19 pandemic, both physically and non-physically. Through the social protection it provides, it is hoped that the elderly can still enjoy the end of their lives in a quality and comfortable condition.

The creation of these conditions is a shared responsibility between the government and society. Law Number 13 of 1998 concerning Elderly Welfare, mandates that efforts to improve the social welfare of the elderly are basically the preservation of religious and cultural values of the nation. The government is tasked with directing, guiding, and creating a supportive atmosphere for the implementation of efforts to improve the social welfare of the elderly (Article 7). The community has the widest right and opportunity to play a role in efforts to improve the social welfare of the elderly (Article 22, paragraph 1).

Various parties have conducted studies or research on social protection for the elderly in general. However, studies / research on the social protection of the elderly especially during the Covid-19 pandemic have not been done much. For this reason, the Social Welfare Research and Development Center (Puslitbangkesos) of the Ministry of Social Affairs R.I. conducted this study, both at social service institutions organized by the government, local government, and the community as information on the implementation of social protection during the Covid-19 pandemic, as well as input for policy development related to social protection for the elderly, especially during the Covid-19 pandemic.

This study aims to identify the social protection of the elderly in social service institutions organized by the government, local government, and the community during the Covid-19 pandemic and knowing the priority needs of these elderly social service institutions in providing social protection during the Covid-19 pandemic.

\section{METHODS}

This rapid assessment approach is a mixed method. Research method characterized by quantitative data collection in the first stage, and then followed by qualitative data collection and analysis in the second stage, in order to support the results of quantitative research conducted in the previous stage [8]. The quantitative approach is used to see the types of social protection provided by elderly social service institutions, which are organized by the central government, local governments, and the community, during the Covid-19 pandemic (February 2020-present). Meanwhile, a qualitative approach is used to obtain the information that has been obtained quantitatively.

As stated, the target of this study is elderly social service institutions organized by the central government, regional governments and the community. Due to the conditions of the Covid-19 pandemic, in which not all elderly social service agencies accept outside parties / guests, elderly social service agencies that are in the green zone are selected, receive guests, and allow land travel to be reached. Meanwhile, data collection on elderly social service institutions organized by the government outside Java was done virtually. In detail, the elderly social service institutions targeted for the study are presented in Table 1 as follows.

Then, the determination of respondents is carried out by nonprobability sampling with the snowball technique, where through elderly social service agencies organized by the government, as a supervisor for elderly social service institutions organized by the community, become the entry point for getting respondents, from managerial and functional elements of service and social workers. Data collection was carried out using several techniques, namely: a questionnaire aimed at the functional service; FGD with elderly service stakeholders in elderly service institutions organized by the local government and the community; observation, and study documentation as well as data and information that are considered relevant. 
Table 1. Target Aging Service Institution for Study

\begin{tabular}{|c|c|c|}
\hline Institution & Location & Method \\
\hline Balai RSLU Budhi Darma & Bekasi District, West Java & Visit \\
\hline Balai RSLU Gau Mabaji & Gowa District, South Sulawesi & Virtual \\
\hline Loka BRSLU Minaula & Kendari City, Southeast Sulawesi & Virtual \\
\hline PSRLU \& PTMP Ciparay & Bandung District, West Java & Visit \\
\hline Satpel RSLU & Karawang City, West Java & Visit \\
\hline Satpel RSLU & Sukabumi City, West Java & Visit \\
\hline LKSLU Caritas & Bekasi City, West Java & Visit \\
\hline LKSLU Islamic Village & Tanggerang District, Banten & Visit \\
\hline LKSLU Nurul Taubat & Bogor District, West Java & Visit \\
\hline
\end{tabular}

This study used a mixed method approach, the quantitative data obtained through the questionnaire is supported by qualitative data, through focus group discussions (FGD) interviews with management elements and functional officers / officials, seven each, especially in Elderly social protection institutions whose data collection is carried out directly, namely: BRSLU Budhi Darma Bekasi, PSRLU Ciparay Bandung, Satpel RSLU Sukabumi and Satpel RSLU Karawang, LKSLU Nurul Taubat Bogor, LKSLU Islamic Village Tangerang, and LKSLU Caritas Bekasi. Meanwhile, data collection at BRSLU Gau Mabaji Gowa and Loka RSLU Minaula Kendari was done virtually. Quantitative data were analyzed descriptively, while qualitative data were analyzed through a process: data reduction, data display, and conclusions to enrich the previously obtained quantitative data.

\section{SOCIAL PROTECTION}

The concepts related to this study include social protection. Social protection is a broad concept and develops in line with community dynamics. In the Indonesian context, prior to the economic crisis in 1997, social protection was not yet a part of the government's priorities. The economic crisis in 1997-1998 caused a multidimensional crisis, causing many Indonesians to fall into poverty, giving awareness about the vulnerability of Indonesia's economic conditions, as well as the importance of social protection for the entire population. Since then, Indonesia has had a social protection system that began with the national Social Safety Net (JPS) policy. The social protection system, which consists of social security and social assistance programs, continues to develop [9].

Limitation on social protection, among others, is stated by the International Labor Organization (ILO), that social protection as a system provided through a series of public policies to minimize the impact of economic and social shocks that can be caused by loss or reduced income as a result of, illness, pregnancy, work accident, unemployment, disability, old age, or death [10]. The World Bank, in the Social Protection and Labor Strategy document, states that social protection includes social safety nets, investment in human resources, and efforts to overcome social segregation. Social protection must consider the real situation and focus more on prevention, not on symptoms and consequences [11].

Meanwhile, the Asian Development Bank (ADB) defines social protection as a set of policies designed to reduce poverty and vulnerability through efforts to improve the capacity of the population to protect themselves from disasters and loss of income. Social protection includes at least five elements, namely social insurance, social assistance, community protection with micro and area-based schemes, labor market, and child protection [12]. According to Law Number 13 of 1998 concerning Elderly Welfare, social protection is an effort by the government and / or society to provide easy services for elderly people with no potential in order to realize and enjoy a reasonable standard of living.

Social protection could be described as all public and private initiatives that provide income or consumption transfers to the poor, protect the vulnerable against livelihood risks, and enhance the social status and rights of marginalized groups within any given country [11]. Meanwhile, social security back to basic principles argued that social protection is generally understood as an integrated intervention by various parties to protect individuals, families and communities from the various risks of everyday life [12]. Which may occur or to overcome the various effects of economic shocks, or to provide support for vulnerable groups in society. Social protection as any initiative by the government, the private sector, or the community to realize the transfer of income or consumption to the poor, protect vulnerable groups from livelihood risks, and improve the social status of marginalized groups [11].

Based on the above definitions, social protection for the elderly during the Civid-19 pandemic referred to in this study is all efforts made, both by the government and society in the framework of providing protection for the elderly, during the Covid-19 pandemic, which focuses on prevention. .

Various social protection efforts for the elderly have been carried out by the government and society in an effort to meet the needs of the elderly. Elderly needs include survival needs, namely: food, clothing, housing, health care; safety and security needs, namely protection 
from things that are dangerous and violent; social needs, namely opportunities to interact in a positive environment; esteem needs, namely: the opportunity to build self-esteem (a sense of respect) and achieve dignity, as well as self-actualization needs, namely opportunities for continuous education and selfdevelopment.

\section{IMPLEMENTATION OF SOCIAL PROTECTION FOR ELDERLY DURING THE COVID PANDEMIC}

In the framework of social protection for the elderly during the Covid-19 pandemic, elderly social protection institutions organized by the central government, local governments and the community made several changes to adapt to the situation.

Overall, 39.75 percent of respondents stated that there was a change in social protection activities for the elderly. Followed by changes in the budget aspect (refocusing) by 28.6 percent, 16.55 percent changes in employee working hours, and 15.1 percent changes in the aspects of infrastructure. In detail, at B-LRSLU, changes in activity aspects were stated by 34.15 percent of respondents, budget changes were stated by 25.61 percent of respondents, changes in infrastructure were stated by 20.73 percent of respondents, and changes in employee working hours were stated by 19.51 percent of respondents. In PS-Satpel-RSLU, 50 percent of changes occurred in the aspects of activities, changes in budget and employee working hours, respectively 20.24 percent of respondents stated, and 9.52 percent of other changes in the aspect of infrastructure. Meanwhile, in the LKSLU, 38.72 percent of changes occurred in the activity aspect, 31.30 percent in the budget aspect and 15.13 percent respectively occurred in the employee's infrastructure and working hours.

This condition is supported by qualitative data from the results of the FGD, on social service / protection institutions organized by the government (central, regional) and the community. This can be seen from the statement made by BRSLU official Budhi Darma,

In current conditions, what we are doing is revising the budget (refocusing and relocating the 2020 Budget); spraying all rooms and guesthouses; preparing Giver Care Workers who directly handle the Covid-19 Elderly; Imposing Special Pickets at Covid-19 temporary shelters; and conduct lockdown and work from home for employees / employees (PJ, 4 Agt., 2020).

Similar information was obtained from PSRLU and TPMP Ciparay Bandung, as social service / protection agencies run by the Regional Government,

“... In this period of the Cavid-19 pandemic, we made changes in terms of services / social protection for $L U$, along with budgeting, and of course the implementation of health protocols. Besides that, we also apply work from home/work from office for employees" (.... Agt., 2020).

Likewise, changes are made to social service / protection institutions run by the community. This is as stated by the management of the Islamic Village LKSLU,

"... in Islamic Village, there are changes in budgeting at institutions, especially for PPE spending, such as: masks, disinfectant fluids, carbolic acid, and body temperature measurement, while still providing basic daily needs" (... Agt., 2020).

In addition, in an effort to maximize social protection for the elderly so that they are not exposed to Covid-19, environmental cleanliness is carried out. In particular, the room designated for elderly activities and of course a place / room for officers. Through FGD, the information was obtained, that cleaning the space / environment of the RSLU Balai-Loka, PS-Satpel RSLU, and LKSLU was quite intensively carried out.

Another effort is to do routine health checks for the elderly every month. Regarding health services for the elderly as beneficiaries, for the elderly social protection institutions managed by the Central Government, namely: Aging Social Rehabilitation Centers because they have their own medical personnel (doctors). So health services are sufficient to be carried out in the institution itself. Meanwhile, the institutions run by the local government are PSRLU and Satpel. RSLU because there are no medical personnel (doctors), but have collaborated with medical personnel at the Community Health Center (Puskesmas) and Regional General Hospital (RSUD). Therefore, regularly the institution can bring in medical personnel as agreed and mutually determined about the time. As for the social service / protection institutions organized by the community, through FGD, information was obtained that in examining the health of the elderly, it depends on the condition of the elderly by visiting a doctor and / or bringing them to a dormitory or elderly boarding house. Even then, if the LKSLU has enough budget to bring in medical personnel. Regarding the Rapid test, generally it is still limited to officers and employees. Even then, the social protection agency for the elderly run by the government and local governments. While the rapid test for the elderly, limited information was obtained for the newly arrived elderly, and even then on government-run institutions. It can be understood that the rapid test activity does need sufficient funds. For institutions organized by the community, the availability of funds for conducting rapid tests is a separate problem.

The implementation of health protocols is also quite difficult to do, namely related to the discipline of wearing masks for the elderly and not an easy matter. Various reasons were stated as "difficulty breathing", "uncomfortable or uncomfortable wearing a mask" and various other reasons. The next difficulty for the elderly 
is maintaining distance, and the next is washing hands using soap in running water. Therefore, the efforts made by the social protection institutions for the elderly to avoid Covid-19 are to make it a habit to do three (3) M, namely: Wearing a mask, keeping distance, and washing hands frequently using soap in running water.

\section{CONCLUSION}

Based on the implementation of social protection during the Covid-19 pandemic at elderly social protection institutions organized by the government, local governments, and the community, it is concluded that social protection for the elderly during the Covid-19 pandemic by these institutions is carried out through changes in activities and budget changes (budget refocusing). Refocusing the budget, especially allocated for spending on health needs directly related to the prevention of Covid-19. Such as: disinfectants, masks, hand soap, medicines, vitamins, personal protective equipment (PPE), rapid tests, and swabs. Changes in activities and budgets in these institutions are based on government policies, in this case the Ministry of Social Affairs responds to national policies in preventing Covid-19.

\section{AUTHORS' CONTRIBUTIONS}

Nurasih Shamadiyah worked analysis and Achmadi Jayaputra carried out survey. All authors contributed to manuscript and all authors approved the final version of the manuscript.

\section{ACKNOWLEDGMENTS}

We would like to thank all elderly social service agencies involved. We also thank the Centre for Community Social Resilience Development of the Ministry of Social Affairs of the Republic of Indonesia for their support.

\section{REFERENCES}

[1] Badan Perencanaan Pembangunan Nasional, Badan Pusat Statistik, United Nations Population Fund. Indonesia Population Projection 2010-2035, Badan Pusat Statistik, Jakarta-Indonesia, 2013

[2] Badan Pusat Statistik. Statistik Indonesia, Badan Pusat Statistik, Jakarta-Indonesia, 2019

[3] World Health Organization. Coronavirus disease 2019 (COVID-19), 2020

[4] Christensen, K., Doblhammer, G., Rau, R., \& Vaupel, J. W. (2009). Ageing populations: the challenges ahead. The Lancet, 374(9696), 11961208. https://doi.org/10.1016/S0140-
[5] Gatimu, S. M., Milimo, B. W., \& Sebastian, M. S. (2016). Prevalence and determinants of diabetes among older adults in Ghana. BMC Public Health, 16, 1174. https://doi.org/10.1186/s12889-016$3845-8$

[6] S Seftiani, D Vibriyanti. The Implementation of Bina Keluarga Lansia (BKL) Program in Urban Areas: An Overview of Common Challenges), Jurnal Kependudukan Indonesia, 15 (1), pp. 59-70, doi:https://doi.org/10.14203/jki.v15i1.533

[7] F, Kusumaastuti, Merawat Kebiasaan Baik, in: Vinda Maya (Eds.), Komunikasi Empati Dalam Pandemi Covid-19, Aspikom Jatim and Buku Litera, Yogyakarta, 2020, pp.115 - 120

[8] J. W., Creswell. Editorial: Mapping the Field of Mixed Methods Research, Journal of Mixed Methods Research, 3(2), pp. 95-108. doi: $10.1177 / 1558689808330883$

[9] Badan Perencanaan Pembangunan Nasional. Perlindungan Sosial di Inonesia: Tantangan dan Arah Kedepan, 2014.

[10] International Labour Office, Social protection: a life cycle continuum investment for social justice, poverty reduction and development, 2003

[11] World Bank, the World Bank's Social Protection and Labor Strategy 2012-2022, 2012.

[12] E, Suharto. Kemiskinan dan Perlindungan Sosial di Indonesia, Alfabeta, Bandung, 2009. 6736(09)61460-4 